\title{
Ellipsis
}

2015

\section{When I Was Thoreau in the Morning}

Brianna Breaux

University of New Orleans

Follow this and additional works at: https://scholarworks.uno.edu/ellipsis

\section{Recommended Citation}

Breaux, Brianna (2015) "When I Was Thoreau in the Morning," Ellipsis: Vol. 42 , Article 20.

DOI: https://doi.org/10.46428/ejail.42.20

Available at: https://scholarworks.uno.edu/ellipsis/vol42/iss1/20

This Poetry is brought to you for free and open access by the Department of English and Foreign Languages at ScholarWorks@UNO. It has been accepted for inclusion in Ellipsis by an authorized editor of ScholarWorks@UNO. For more information, please contact scholarworks@uno.edu. 


\section{When I Was Thoreau in the Morning}

Brianna Breaux

Andrea Saunders Gereighty / Academy of American Poets Award $3^{\text {rd }}$ Place

Assume the Gulf's wide mouth, a sharp outcrop

of rock licked with sea-slicked lichen. Assume:

alone, dawn. I beat my bones on the sand

and run, tight-skinned, not she but all body

and all outside, all hoping animal.

A mile out, I swim to the rocks and out

stretch across the water, stretch out and sun

salute. From the jetty just opposite

a fisherman also alone, youngish

and so in his body's sunrise wades waist

deep to ask for bait. Closer, I see he

clearly; almost a heron, arms high

to still smoke in the spring tide. I answer.

Assume damp flannel, conscious, skin-tight cling:

I've none and sorry, and assume, saying

so tamely, she. 